\title{
GAMBARAN KELENGKAPAN ANIENATAL CARE TERPADU DI PUSKESMAS TEPUS II GUNUNGKIDUL
}

\author{
Bundarini, Enny Fitriahadi \\ Program Studi Kebidanan Program Sarjana Terapan Kebidanan Universitas 'Aisyiyah Yogyakarta Jalan Siliwangi No.63 \\ Ring Road Barat Nogotirto Gamping Sleman Yogyakarta, \\ Email : bundarinii05@gmail.com
}

\begin{abstract}
ABSTRAK
Pelayanan antenatal diberikan oleh tenaga kesehatan terlatih untuk ibu selama masa kehamilannya, dilaksanakan sesuai dengan standar pelayanan antenatal yang ditetapkan dalam standar pelayanan kebidanan. Pelayanan antenatal care terpadu meliputi 10 standar yang dikenal dengan $10 \mathrm{~T}$. Tujuan penelitian ini mengetahui gambaran kelengkapan pelayanan Antenatal Care terpadu di Puskesmas Tepus II tahun 2018. Penelitian ini menggunakan metode kuantitatif dengan design deskriptif survey melalui pendekatan cross sectional. Pengambilan sampel menggunakan metode total sampling sebanyak $200 \mathrm{ibu}$. Analisis data menggunakan analisis univariat. Pengambilan data dengan study dokumentasi menggunakan instrument lembar observasi dengan merekap data yang ada didalam kohort ibu, register kunjungan, rekam medis pasien dan buku KIA. Hasil penelitian menunjukkan ibu hamil yang memperoleh pelayanan antenatal standar $10 \mathrm{~T}$ lengkap sebesar 144 orang (72\%) dan yang memperoleh pelayanan ANC standart 10 T kurang lengkap 57 (28\%). Standar pemeriksaan laboratorium deteksi IMS/ shipilis paling rendah yaitu 144 (72\%). Ibu hamil disarankan segera melakukan pemeriksaan kehamilan setelah diketahui hamil agar selama kehamilan memperoleh pelayanan sesuai standar. Tingkat pendidikan ibu, keterbatasan sarana prasarana serta sumber daya kesehatan menyebabkan ibu hamil kurang lengkap mendapatkan pelayanan ANC terpadu.
\end{abstract}

Kata kunci : antenatal care terpadu; kelengkapan

\section{ABSTRACT}

Antenatal care is provided by well-trained health professionals for mothers during their pregnancy, and is carried out in accordance with the standards of antenatal care stipulated in midwifery service standards. Integrated antenatal care services include 10 standards known as $10 \mathrm{~T}$. The purpose of this study was to describe the complete description of integrated Antenatal Care services at Tepus II District Health Center in 2018. This study used a quantitative method with a descriptive survey design through a cross sectional approach. Sampling method used total sampling method of 200 mothers. Univariate analysis was used as data analysis. Data collection applied documentation study by using observation sheets by recapitulating data in the maternal cohort, visit registers, patient medical records and $\mathrm{MCH}$ books. The results of the study on pregnant women who received the $10 \mathrm{~T}$ standard Antenatal Care reached 144 people (72\%), and those who received incompletestandard $10 T$ Antenatal Care services were 57 (28\%). The lowest standard of SexualTransmissionInfection/ syphilis detection laboratory testing reached 144 (72\%). Mother's educationlevel, limited infrastructure and health resources made pregnant women to get incomplete integrated Antenatal Care services. Pregnant women are suggested to immediately carry out a pregnancy checkup after they are found to be pregnant so that during pregnancy they get services according to standards.

Keywords : completeness; integrated antenatal care 


\section{LATAR BELAKANG}

Pelayanan antenatal merupakan pelayanan kesehatan oleh tenaga kesehatan terlatih untuk ibu selama masa kehamilannya, dilaksanakan sesuai dengan standar pelayanan antenatal yang ditetapkan dalam standar pelayanan kebidanan. Perawatan antenatal adalah perawatan sebelum persalinan. Pelayanan antenatal yang berkualitas dapat mendeteksi terjadinya risiko pada kehamilan yaitu mendapatkan akses perawatan kehamilan berkualitas, memperoleh kesempatan dalam deteksi dini terhadap komplikasi yang mungkin timbul sehingga kematian maternal dapat dihindari (Mufdlilah, 2009).

Kehamilan merupakan proses fisiologis, akan tetapi karena suatu hal kehamilan dapat berkembang menjadi patologis sehingga berisiko baik terhadap ibu maupun janin yang dikandungnya. Kehamilan risiko tinggi dan faktor risiko adalah keadaan kehamilan dengan ibu atau perinatal dalam keadaan membahayakan selama kehamilan maupun persalinan. Perkiraan insidensi kehamilan risiko tinggi sangat berfariasi tergantung pada kriteria dan ketepatan pengumpulan data. Meskipun demikian menurut sebagian standart kehamilan yang terjadi di Amerika Serikat $20 \%$ berada pada risiko tinggi dan $5 \%$ kehamilan pada risiko sangat tinggi. Sekitar separuh kasus dapat dikenali dalam masa antenatal, namun seperempat kasus lainnya dikenali selama masa persalinan(Benson \& Pernoll, 2008).

Diawal era Sustainable Development Goals (SDGs), kehamilan terkait morbiditas dan mortalitas ibu menjadi perhatian semua negara. WHO juga memperkirakan bahwa sekitar $15 \%$ dari seluruh ibu hamil akan berkembang menjadi komplikasi, yang dapat dicegah melalui pemberian asuhan kehamilan yang berkualitas.

Pemeriksaan kehamilan diharapkan mampu mencegah kematian ibu baik karena penyebab langsung maupun penyebab tidak langsung. Program yang digalakkan dalam upaya deteksi komplikasi dan risiko pada saat kehamilan adalah dengan pelaksanaan ANC terpadu seperti tertuang dalam Peraturan Menteri Kesehatan Nomor 97 tahun 2014 tentang
Pelayanan Kesehatan masa sebelum hamil, masa hamil, persalinan dan masa sesudah melahirkan, menyelenggarakan pelayanan kontrasepsi, serta pelayanan kesehatan seksual.

Pelaksanaan Antenatal Care di beberapa Negara dilaporkan masih rendah seperti di beberapa Negara bagian di Nigeria seperti dilaporkan dalam jurnal oleh (Onyeajam, Xirasagar, Khan, Hardin, \& Odutolu, 2018). Hal ini ditunjukkan dari kepuasan pasien yang sangat dipengaruhi oleh beberapa faktor yaitu dalam pelayanan seperti jam buka, ruang yang nyaman, pelayanan yang terburu buru dan respon layanan yang cepat, ketersediaan alat, sikap empati, non diskriminatif serta komunikasi pemberi layanan.

Data cakupan kunjungan K1 di DIY pada tahun 2017 sudah mencapai $100 \%$ disemua Kabupaten. Untuk kunjungan K4 di DIY sudah mencapai 91,85 \% dengan angka tertinggi di kabupaten Sleman (96,03\%), dan terendah di Kabupaten Gunungkidul (86,02 \%) (Dinkes DIY,2017).

Hasil studi pendahuluan di Puskesmas Tepus II, data PWS KIA yang ada di Wilayah puskesmas Tepus II tahun 2017 cakupan Antenatal careterpadu adalah sebagai berikut ; cakupan K1 ibu hamil $100 \%$, cakupan K4 ibu hamil $75,22 \%$, ibu hamil diperiksa dokter umum $69,46 \%$, ibu hamil diperiksa dokter gigi $73,12 \%$ ibu hamil di ukur BB dan TB 100\%, ditentukan status gizi melalui pengukuran lila $100 \%$, penentuan letak dan denyut jantung janin belum ada datanya, mendapatkan tablet FE 90 tablet $61,06 \%$, mendapatkan imunisasi TT atau skrening TT $100 \%$, dilakukan pengukuran tinggi fundus uteri belum ada data , dilakukan pemeriksaan HIV 52,86\% ,pemeriksaan HBSAG 69,16\%, pemeriksaan IMS (Shypilis) $0 \%$, temu wicara dan mendapatkan tata laksana kasus belum ada data dari target keseluruhan ANC terpadu standart 10 T adalah $100 \%$ (Puskesmas Tepus II, 2017).

Berdasarkan latar belakang diatas penulis tertarik untuk mengetahui gambaran kelengkapan Antenatal Care terpadu di Puskesmas Tepus II Gunungkidul tahun 2018. 


\section{METODE}

Penelitian ini merupakan penelitian kuantitatif dengan design deskriptif survey yaitu penelitian yang mencoba menyajikan data secara kuantitatif dari suatu populasi tertentu dengan tujuan menggeneralisasi populasi berdasarkan sampel yang sudah ditentukan, dengan pendekatan waktu cross sectional. Pengambilan sampel dengan total sampling sebanyak 201 ibu yang melahirkan pada tahun 2018 dengan 1 orang sampel drop out sehingga sampel 200 orang.

\section{HASIL}

\section{Karakteristik Responden.}

\section{Tabel 1 Distribusi Frekuensi Subyek Penelitian}

\begin{tabular}{|c|c|c|c|}
\hline No. & Karakteristik & $\begin{array}{l}\text { Frekuensi } \\
(n=200)\end{array}$ & $\begin{array}{l}\text { Persentase } \\
(\%)\end{array}$ \\
\hline \multirow[t]{4}{*}{1} & Umur & & \\
\hline & a. $<20$ tahun & 21 & 10,5 \\
\hline & b. $20-35$ tahun & 159 & 79,5 \\
\hline & c. $>35$ tahun & 20 & 10,0 \\
\hline \multirow[t]{5}{*}{2} & Pendidikan & & \\
\hline & a. SD & 35 & 17,5 \\
\hline & b. SMP & 112 & 56,0 \\
\hline & c. SMA/SMK & 42 & 21,0 \\
\hline & d. PT & 11 & 5,5 \\
\hline \multirow[t]{6}{*}{3} & Pekerjaan & & \\
\hline & a. $I R T$ & 131 & 65,5 \\
\hline & b. Swasta & 53 & 26,5 \\
\hline & c. Petani & 13 & 6,5 \\
\hline & d. Pedagang & 1 & 0,5 \\
\hline & e. PNS/ Perdes & 2 & 1,0 \\
\hline \multirow[t]{4}{*}{4} & Paritas & & \\
\hline & a. Primigravida & 76 & 38,0 \\
\hline & $\begin{array}{l}\text { b. Secundi } \\
\text { gravida }\end{array}$ & 84 & 42,0 \\
\hline & c. Multigravida & 40 & 20,0 \\
\hline
\end{tabular}

Tabel 1 menunjukkan karakteristik ibu hamil paling banyak usia antara 20-35 tahun sebanyak 159 orang $(79,5 \%)$ dengan rata rata berpendidikan terbanyak tamat SMP sebesar 112 (56\%), berstatus obstetri secundigravida sebesar 84 orang (42\%) dan berpekerjaan paling banyak sebagai ibu rumah tangga 131 orang $(65,5 \%)$ (tabel1).

Usia ibu hamil terbanyak berada pada usia 20-35 tahun sebanyak 159 orang (79,5\%), hal ini sesuai dengan usia hamil yang disarankan bahwa seorang perempuan sebaiknya hamil pada usia antara 20-35 tahun dimana usia tersebut adalah usia reproduksi sehat yang minimal risiko. Hal ini sejalan dengan penelitian yang dilakukan oleh (Kaimmudin, Pangemanan, \& Bidjuni,2018), tentang Hubungan Usia ibu saat hamil dengan kejadian Hipertensi di RSU GMIM Pancaran Kasih Manado bahwa usia kurang dari 20 tahun dan lebih dari 35 tahun meningkatkan risiko kejadian hipertensi dalam kehamilan dan komplikasi lain karena anatomi yang sudah tidak lentur lagi.

Tingkat pendidikan responden sebagian besar adalah SMP sebanyak 112 orang (56\%) dimana SMP adalah pendidikan dasar minimal yang disyaratkan oleh pemerintah yaitu wajib belajar 9 tahun. SMP masuk dalam kategori tingkat pendidikan rendah dimana akan sulit dalam menerima informasi baru. Hal ini sejalan dengan penelitian yang dilakukan oleh (Corneles \& Losu, 2015) bahwa tingkat pendidikan ibu berpengaruh terhadap tingkat pengetahuan ibu tentang kehamilan risiko tinggi di kota belitung. Hal ini sejalan dengan penelitian yang dilakukan oleh (Puspitasari, Hakimi, \& Nurhidayati, 2017) bahwa usia, pekerjaan, pengetahuan dan pendapatan tidak ada hubungan dengan kunjungan antenatal care, sedangkan pendidikan dan jarak kehamilan ada hubungan dengan pemeriksaan kehamilan.

Paritas terbanyak adalah secundigravida (kehamilan kedua) sebesar 84 (42\%). Paritas kedua adalah paritas yang paling aman untuk hamil. Menurut (Hipson, 2016) bahwa umur, paritas dan tingkat pendidikan mempengaruhi kejadian eklapmsia pada ibu hamil. Dimana paritas pertama meningkatkan kejadian eklampsia, begitu juga paritas 3 dan selebihnya. Sehingga paritas 2 adalah paritas yang paling aman untuk kehamilan.

Pekerjaan responden paling banyak ibu rumah tangga sebesar 131 (65,5\%). Banyak ibu hamil yang memutuskan untuk berhenti bekerja karena kehamilannya. Hal ini sejalan dengan penelitian yang dilakukan oleh dibeberapa negara seperti dimuat dalam 
(Kompas, 2016) bahwa perempuan yang bekerja 40 jam per minggu cenderung melahirkan bayi dengan ukuran lebih kecil.

\section{Standart pelayanan ANC Terpadu $10 \mathrm{~T}$}

\section{Tabel 2 Distribusi frekuensi standar $10 \mathrm{~T}$ dalam Pelayanan ANC Terpadu di Puskesmas Tepus II tahun 2018}

\begin{tabular}{|c|c|c|c|}
\hline No. & $\begin{array}{c}\text { Standart ANC } \\
\text { Terpadu }\end{array}$ & $\begin{array}{c}\text { Frekuensi } \\
(n=200)\end{array}$ & $\begin{array}{c}\text { Persentase } \\
(\%)\end{array}$ \\
\hline 1 & $\begin{array}{l}\text { Timbang BB dan } \\
\text { ukur TB }\end{array}$ & 200 & 100 \\
\hline 2 & Ukur Tekanan Darah & 200 & 100 \\
\hline 3 & $\begin{array}{l}\text { Tentukan status Gizi } \\
\text { (LILA) }\end{array}$ & 200 & 100 \\
\hline 4 & Pengukuran TFU & 200 & 100 \\
\hline 5 & $\begin{array}{l}\text { Tentukan Presentasi } \\
\text { dan DJJ }\end{array}$ & 200 & 100 \\
\hline 6 & Skrining status TT & 200 & 100 \\
\hline 7 & $\begin{array}{l}\text { Pemberian tablet FE } \\
\text { minimal } 90 \text { tablet }\end{array}$ & 172 & 86,0 \\
\hline \multirow[t]{7}{*}{8} & $\begin{array}{l}\text { Pemeriksaan } \\
\text { laboratorium rutin } \\
\text { dan khusus }\end{array}$ & & \\
\hline & a. Haemoglobin & 178 & 89,0 \\
\hline & b. Golongan darah & 176 & 88,0 \\
\hline & c. Protein urine & 161 & 80,5 \\
\hline & d. Rapid test HIV & 167 & 83,5 \\
\hline & e. HBSAG & 167 & 83,5 \\
\hline & f. Shipilis/ IMS & 144 & 72,0 \\
\hline 9 & Tata laksana kasus & 171 & 85,5 \\
\hline 10 & $\begin{array}{l}\text { Temu } \\
\text { Konseling }\end{array}$ & 200 & 100 \\
\hline
\end{tabular}

Tabel 2 menunjukkan bahwa pelayanan ANC terpadu standar penimbangan berat badan dan ukur tinggi badan, pengukuran tekanan darah, penentuan status gizi, pengukuran TFU, penentuan presentasi dan DJJ, skrining imunisasi TT serta temu wicara/ konseling mencapai angka tertinggi yaitu 100\% sedangkan pemeriksaan laboratorium yaitu deteksi IMS melalui pemeriksaan shipilis mencapai angka terendah sebanyak 144 orang (72\%).

\section{PEMBAHASAN}

\section{Timbang Berat badan dan ukur TB}

Pelayanan ANC terpadu standar pertama yaitu timbang berat badan dan ukur tinggi badan dilakukan pada 200 ibu (100\%) dari total ibu hamil yang melakukan ANC terpadu. Setiap ibu hamil wajib mendapatkan pelayanan ANC sesuai standar yaitu $10 \mathrm{~T}$ dimana standar pertama adalah timbang berat badan dan ukur tinggi badan. Penimbangan berat badan dilakukan setiap kali kunjungan sedangkan pengukuran tinggi badan dilakukan pada awal kunjungan (Kemenkes,2014).

Penimbangan berat badan ibu hamil digunakan sebagai indikator pertumbuhan dan kesejahteraan janin. Rata rata kenaikan berat badan ibu hamil selama kehamilan adalah 10 $12,5 \mathrm{~kg}$. Pertambahan berat badan ibu menggambarkan status gizi dan kesehatan ibu serta pertumbuhan janin. Ibu yang mempunyai BB normal/ideal rata-rata kenaikan $1 \mathrm{~kg}$ tiap bulan. Ibu hamil yang kekurangan gizi berisiko melahirkan bayi kecil dengan berat lahir kurang dari 2500 gram. Kenaikan BB ibu selama hamil berkaitan dengan banyak sedikitnya asupan makanan ibu. Oleh karena itu ibu hamil harus makan beraneka ragam dan lebih banyak satu porsi daripada sebelum hamil (Kemenkes, 2018).

\section{Pengukuran Tekanan Darah}

Standar pengukuran tekanan darah sebanyak 200 orang (100\%). Pengukuran tekanan darah pada ibu hamil dilakukan pada setiap kali kunjungan. Pada trimester pertama ibu hamil disarankan melakukan pemeriksaan satu kali setiap bulan sampai usia kehamilan 27 minggu. Pada usia kehamilan 28 sampai 32 minggu pemeriksaan kehamilan dilakukan 2 minggu sekali dan pada usia kehamilan $>33$ minggu pemeriksaan kehamilan dilakukan seminggu sekali (Saminem, 2009).

Pengukuran tekanan darah pada setiap kali kunjungan dilakukan untuk mengetahui apakah ibu masuk dalam kehamilan berisiko atau tidak. Peningkatan tekanan darah yang terjadi sebelum kehamilan 20 minggu dimana TD > 140/90 mmHg, tidak terdapat edema, protein urine negatif dan tidak terdapat penyakit ginjal termasuk dalam kategori hipertensi dalam kehamilan.

Kenaikan tekanan darah setelah kehamilan 20 minggu dimana TD systole $140-160 \mathrm{mmHg}$ dan diastole $90-100 \mathrm{mmHg}$, disertai protein urin +2 dan edema termasuk dalam preeklampsia 
ringan. Sedangkan kenaikan tekanan darah pada usia kehamilan $>20$ minggu dengan TD > 160/100 protein uria +3 dan bengkak termasuk dalam kategori preeklampsia berat. Apabila ditemukan ibu hamil dengan hipertensi dalam kehamilan maka segera dilakukan rujukan ke RS (Dinkes Gunungkidul, 2017).

\section{Tentukan status Gizi (LILA)}

Standar penentuan status Gizi dengan pengukuran Lingkar Lengan Kiri Atas (LILA) dilakukan pada 200 ibu (100\%).Kondisi janin didalam kandungan sangat dipengaruhi oleh keadaan gizi ibu baik sebelum maupun selama kehamilan. Wanita hamil berisiko mengalami Kekurangan Energi Kronis (KEK) jika memiliki Lingkar Lengan Atas (LILA) $<23,5 \mathrm{~cm}$ ( tabel 3).

Ibu hamil dengan KEK berisiko melahirkan bayi dengan berat badan lahir rendah (BBLR). BBLR akan membawa risiko kematian, gangguan pertumbuhan dan perkembangan anak. KEK juga bisa menjadi penyebab tidak langsung kematian ibu. Hasil riskesdas 2018 menunjukkan bahwa proporsi ibu hamil KEK 23,3 \% dimana angka ini menurun dari kejadian ibu hamil KEK tahun 2013 yaitu 24,2 \% (Kemenkes, 2018).

Ibu hamil yang ditemukan mengalami KEK mendapatkan pelayanan konsultasi gizi dengan nutrisionis dan memperoleh PMT baik PMT dari Pusat maupun pengadaan dari Puskesmas. PMT yang diberikan kepada ibu hamil KEK berupa makanan tambahan berupa biscuit, kacang hijau, gula jawa, abon, mie yang diberikan selama 90 hari. Hal ini sesuai dengan dara riskesdas tahun 2018 data ibu hamil yang memperoleh PMT sebanyak 25,2\%.

Kenyatannya di Indonesia masih banyak ibu hamil yang kurus maupun anemia. Hal ini disebabkan asupan makanannya selama hamil tidak mencukupi untuk dirinya sendiri dan untuk janinnya. Selain itu juga diperparah kondisi beban kerja ibu hamil yang mungkin lebih berat dibandingkan sebelum hamil (Kemenkes, 2015).

\section{Pengukuran Tinggi Fundus Uteri (TFU)}

Standar pengukuran TFU dilakukan pada 200 ibu (100\%). Pengukuran Tinggi Fundus
Uteri (TFU) dapat dijadikan perkiraan usia kehamilan. Selain untuk menentukan usia kehamilan pengukuran TFU digunakan sebagai indikator pertumbuhan janin. Tinggi fundus uteri yang stabil atau tetap dan turun dapat dijadikan indikator retardasi/ gangguan pertumbuhan janin. Namun sebaliknya tinggi fundus uteri yang meningkat secara berlebihan mengidentifikasi adanya jumlah janin lebih dari satu atau adanya hidramnion. Pengukuran TFU harus dilakukan dengan tehnik konsisten dan alat ukur yang sama (Kusmiyati, 2010).

\section{Tentukan presentasi dan Denyut Jantung Janin (DJJ)}

Penentuan presentasi dan denyut jantung janin berdasarkan tabel 3 dilakukan pada 200 ibu (100\%). Kehamilan dibagi dalam tiga trimester yaitu trimester pertama usia 0-12 minggu, trimester kedua 13-27 minggu dan trimester ketiga 28-40 minggu. Diagnosis kehamilan bisa dilihat dari tanda pasti diantaranya adalah terdengar DJJ ,terasa gerakan janin, eraba bagian janin dan terdapat rangka janin. $t$

Letak janin dibagi menjadi letak membujur/melintang, habitus (fleksi/defleksi) posisi (menentukan letak kepala) presentasi (menentukan bagian terendah letak kepala, letak sungsang atau letak lintang). Letak belakang kepala ditemukan pada $95 \%$ kehamilan karena sesuai dengan sumbu uterus. Fundus uteri merupakan tempat yang luas sehingga dengan bokong. Kepala merupakan bagian yang berat sehingga berada dibawah. Jumlah janin dengan letak sungsang 3,5 \% dan letak lintang 0,5\%. Punggung kiri lebih banyak daripada punggung kanan (Saminem, 2009).

\section{Skrining status TT}

Tabel 3 sebanyak 200 ibu (100\%) ibu ditentukan status TT nya pada saat ANC. Penentuan status TT dilakukan pada saat kontak pertama ibu dengan tenaga kesehatan. Skrining status TT ditentukan dari riwayat imunisasi TT sebelumnya.

Standar penimbangan berat badan dan ukur tinggi badan, ukur tekanan darah,tentukan 
status gizi, pengukuran TFU, tentukan presentasi dan DJJ serta skrining status TT mencapai 100\%. Angka ini tertinggi dibandingkan standar yang lain. Dari seluruh populasi ibu hamil yang melahirkan pada tahun 2018 sebanyak 201 orang, satu orang ibu hamil tidak melakukan pemeriksaan ANC selama kehamilan. Beberapa faktor menyebabkan ibu tidak melakukan pemeriksaan kehamilan diantaranya dilihat dari karakteristik ibu bahwa pendidikan dasar SD dan SMP mencapai angka 73,5\%. Hal ini sejalan dengan penelitian yang dilakukan oleh (Addina, 2018) terhadap 100 responden dimana 81orang usia 20-35 tahun dan 38 berpendidikan rendah. Dari hasil chi square nilai $p$ value untuk usia 0,130 dan untuk tingkat pendidikan 0,007 sehingga kesimpulannya tidak ada hubungan antara usia ibu dengan kepatuhan periksa akan tetapi ada hubungan antara tingkat pendidikan dengan kepatuhan ANC di RS Pekajangan.

Hasil penelitian (Irianti, 2017) menyatakan bahwa semakin tinggi pendidikan ibu semakin mudah menerima informasi. Seseorang dengan tingkat pendidikan rendah cenderung lebih sulit menerima informasi lebih tertutup dan sulit mengambil keputusan. Akibatnya bila ada informasi baru penerimaannya lebih lambat. Orang dengan pendidikan lebih tinggi cenderung lebih terbuka, mudah menerima informasi. Dengan mendapat informasi lebih banyak ibu akan menilai apakah persepsi yang dimiliki benar atau salah.

\section{Pemberian tablet Fe minimal 90 tablet.}

Ibu hamil yang mendapatkan tablet FE 90 tablet sebanyak 172 (86,0\%). Standar ANC terpadu ketujuh adalah pemberian tablet $\mathrm{Fe}$ minimal 90 tablet selama kehamilan. Angka ini lebih rendah dari target nasional $95 \%$. Diperkirakan $41,8 \%$ ibu hamil di seluruh dunia mengalami anemia. Paling tidak setengahnya disebabkan karena kekurangan zat besi. Ibu hamil dikatakan anemia bila kadar hemoglobin kurang dari $11 \mathrm{mg} / \mathrm{L}$. Anemia pada ibu hamil dihubungkan dengan meningkatnya kelahiran prematur, kematian ibu dan anak serta penyakit infeksi. Anemia defisiensi besi pada ibu hamil dapat mempengaruhi pertumbuhan dan perkembangan janin saat kehamilan maupun setelahnya (Kemenkes, 2018).

Ibu hamil dianjurkan mengonsumsi paling sedikit 90 pil zat besi selama kehamilan. Melalui pemeriksaan ANC diharapkan ibu hamil mendapatkan minimal 90 tablet Fe dan dapat mengonsumsi dengan benar. Hal ini sejalan dengan penelitian yang dilakukan oleh (Lesilolo, Engka, \& Wunguow, 2016) bahwa ada hubungan ANC dengan kadar hemoglobin, dimana dari hasil uji chi square pada tingkat kemaknaan $95 \%$ menunjukkan nilai $p=0,047$ lebih kecil dari nilai $\alpha=0,05$ menunjukkan bahwa terdapat hubungan antara antenatal terhadap hemoglobin.

Tablet Fe yang diterima ibu sebanyak 90 tablet harus dipantau apakah tablet besi tersebut diminum oleh ibu hamil atau tidak. Tingginya prevalensi anemia dipengaruhi juga oleh kurangnya pengetahuan serta sikap ibu hamil terutama kepatuhan ibu dalam mengkonsumsi tablet Fe. Kepatuhan ibu terhadap konsumsi fe dapat ditingkatkan dengan peningkatan pemberian pendidikan kesehatan (Makmun \& Ismarwati, 2016).

\section{Pemeriksaan laboratorium rutin dan khusus}

Pemeriksaan hemoglobin sebanyak 178 (89\%), golongan darah 176 (88\%), protein urine 161 (80,5\%), rapid test HIV 167 (83,5\%), HBSAG 167 (83,5\%) dan shipilis 144 (72\%). Pemeriksaan laboratorium rutin dan khusus untuk ibu hamil terdiri dari pemeriksaan haemoglobin, golongan darah, protein urine, rapid test HIV, HBSAG dan Shipilis.

Peneliti berpendapat bahwa untuk pemeriksaan laboratorium baik rutin dan khusus masih terkendala ketersediaan reagen yang belum mencukupi, tenaga laborat yang hanya 1 orang dan pemahaman bidan belum sama serta kebijakan tripel elimination muncul setelah pertengahan tahun.

Pemeriksaan laboratorium mencapai angka yang paling rendah dibandingkan dengan standar yang lain dalam ANC terpadu. Hal ini sejalan dengan penelitian yang dilakukan (Mikrajab dan Rahmawati, 2016) bahwa untuk pemeriksaan IMS masih belum bisa dilakukan 
karena keterbatasan alat pemeriksaan dan petugas yang belum dilatih.

Rendahnya cakupan pemeriksaan laborat sejalan dengan penelitian yang dilakukan oleh (Kusyanti \& Maydianasari, 2019) bahwa responden merasakan bahwa untuk pelayanan di laborat banyak kendala saat pasien mau periksa ternyata petugas ada rapat atau dinas luar, sehingga tidak terlayani sesuai jadwal dan pasien harus datang lagi, selain itu tugas laboran mempunyai dobel job.

Hasil penelitian ini menunjukkan bahwa semua ibu hamil yang melakukan pemeriksaan test Sipilis/ IMS, HBSAGdan HIV test berdasarkan inisiasi petugas (TIPK). Hal ini sejalan dengan penelitian yang dilakukan oleh (Oktavia \& Lolli, 2018) bahwa semua ibu hamil yang melakukan test HIV berdasarkan inisiatif petugas kesehatan dan tidak ada ibu hamil yang melakukan test atas inisiatif sendiri. Peran konselor yang baik membantu ibu hamil untuk secara sukarela untuk mengikuti test HIV.Kebijakan test HIV, IMS dan HBSAG sesuai dengan kebijakan pemerintah tentang triple elimination.

\section{Tata Laksana Kasus}

Standar tata laksana kasus mencapai 171 orang $(85,5 \%)$. Standar tata laksana kasus dimaksudkan untuk memberikan penatalaksanaan secara khusus masalah diluar kehamilan yang dialami ibu berkaitan dengan penyakit lain yaitu pemeriksaan kesehatan umum dan kesehatan gigi.

Dalam kehamilan terjadi perubahanperubahan fisiologis di dalam tubuh seperti perubahan system kardiovaskuler, hematologi, respirasi dan endokrin. Perubahan fisiologis tersebut diantaranya penurunan $\mathrm{PH}$ saliva, morning sickness, perubahan tingkah laku diluar kebiasaan yang menyebabkan ibu sering kali mengabaikan kebersihan dirinya termasuk kebersihan giginya sehingga ibu hamil sangat rawan atau peka terhadap penyakit gigi dan mulut (Kemenkes, 2012).

Permasalahan yang sering muncul karena perubahan hormonal yang dapat menyebabkan kelainan rongga mulut antara lain peradangan pada gusi (gingivitis), timbulnya benjolan pada gusi antara 2 gigi yang disebut epulis gravidarum. Selama kehamilan tingkat progesteron pada ibu hamil 10 kali lebih tinggi dari biasanya. Hal ini meningkatkan pertumbuhan bakteri tertentu yang menyebabkan peradangan gusi. Disamping itu perubahan kekebalan tubuh selama kehamilan menyebabkan reaksi tubuh yang berbeda dalam menghadapi bakteri penyebab radang gusi.

Kehamilan tidak langsung menyebabkan gigi berlubang atau menjadi lebih cepatnya proses gigi berlubang yang sudah ada pada masa kehamilan. Faktor faktor yang menyebabkan cepatnya proses gigi berlubang yang sudah ada pada wanita hamil diantaranya $\mathrm{PH}$ saliva yang lebih asam. Gigi berlubang dapat menyebabkan rasa ngilu, pusing, sakit berdenyut dan bahkan pipi bengkak.

Pemeliharaan kesehatan gigi dan mulut bermanfaat untuk menjaga kondisi janin agar tetap tumbuh dan berkembang secara sehat dan sempurna, serta mencegah terjadinya kelahiran bayi dengan berat badan tidak normal atau kelahiran prematur. Penyakit gigi dan mulut yang tidak dirawat dapat menjadi sumber infeksi dan bisa menyebar melalui peredaran darah ke organ-organ tubuh yang lain misalnya ke jantung, ginjal, saluran pencernaan, kulit dan mata.

\section{Temu Wicara / Konseling}

Temu wicara konseling sebanyak 200 orang (100\%). Hal ini dilakukan pada saat pemeriksaan kehamilan sesuai dengan permasalahan yang ditemukan menggunakan media yang ada diantaranya adalah dengan menggunakan buku KIA.

Pemberian pelayanan antenatal care terpadu merupakan pelayanan komprehensif dan berkualitas yang dilakukan melalui pemberian pelayanan dan konseling kesehatan termasuk stimulasi dan gizi agar kehamilan berlangsung sehat dan janinnya lahir sehat dan cerdas. Deteksi dini masalah, penyakit dan penyulit/komplikasi kehamilan, penyiapan persalinan yang bersih dan aman, perencanaan, antisipasi dan persiapan dini untuk melakukan rujukan jika terjadi penyulit/komplikasi, penatalaksanaan kasus 
serta rujukan cepat dan tepat bila diperlukan. Di dalam konseling Melibatkan ibu, suami dan keluarga dalam menjaga kesehatan dan gizi ibu hamil, menyiapkan persalinan dan kesiagaan bila terjadi penyulit/komplikasi (Kemenkes, 2014).

Peran lintas sektoral dalam hal ini sangat diperlukan dalam penggerakan kesadaran masyarakat. Peran dan Dukungan masyarakat dalam pelaksanaan pelayanan kehamilan dapat berupa Program Perencanaan Persalinan dan Pencegahan Komplikasi (P4K), penyelenggaraan kelas ibu hamil, kemitraan bidan dan dukun serta rumah tunggu kelahiran. Peran masyarakat tersebut dapat dikembangkan sesuai dengan kondisi dan kebutuhan masyarakat setempat (Kemenkes, 2014).

Program Perencanaan Persalinan dan Pencegahan Komplikasi merupakan suatu kegiatan dalam rangka meningkatkan cakupan dan mutu pelayanan kesehatan bagi ibu dan bayi baru lahir. kegiatan P4K dilakukan melalui peningkatan peran aktif suami, keluarga dan masyarakat dalam merencanakan persalinan yang bersih dan aman dan persiapan menghadapi komplikasi kehamilan, persalinan dan nifas termasuk perencanaan KB pasca melahirkan (Kemenkes, 2014).

Kegiatan dalam P4K meliputi pendataan sasaran, penyiapan donor darah, penyiapan tabungan ibu bersalin, penyiapan ambulans/tranportasi, pengenalan tanda bahaya kehamilan dan persalinan serta penandatanganan amanat persalinan. Kegiatan P4K tersebut dilakukan saat temu wicara/konseling dalam ANC Terpadu.

Kelengkapan pelayanan ANC Terpadu Tabel 3 Distribusi Kelengkapan Pelayanan ANC Terpadu di Puskesmas Tepus II tahun 2018

\begin{tabular}{cccc}
\hline No. & $\begin{array}{c}\text { Standart ANC } \\
\text { Terpadu }\end{array}$ & $\begin{array}{c}\text { Frekuensi } \\
(\mathrm{n}=200)\end{array}$ & $\begin{array}{c}\text { Persentase } \\
(\%)\end{array}$ \\
\hline 1 & Lengkap & 144 & 72 \\
2 & Tidak lengkap & 56 & 28 \\
& Jumlah & 200 & 100 \\
\hline
\end{tabular}

Tabel 3 menunjukkan ibu hamil yang memperoleh pelayanan ANC terpadu lengkap 10 T sebanyak 144 orang (72\%) sedangkan Ibu hamil yang mendapatkan pelayanan ANC terpadu tidak lengkap sebesar 57 orang (28\%).

Hal ini sesuai dengan penelitian yang dilakukan oleh (Septiningsih, 2018) bahwa dari 43 ibu hamil yang melakukan ANC, 31 orang (72,1\%) mendapatkan ANC sesuai standar dan 12 orang ( $27,9 \%)$ mendapat ANC kurang sesuai standar.

Peneliti berpendapat ibu hamil yang belum lengkap dalam memperoleh pelayanan $10 \mathrm{~T}$ dikarenakan beberapa faktor diantaranya adalah keterbatasan tenaga kesehatan yang memberi pelayanan yaitu dokter umum, dokter gigi dan tenaga laboran yang hanya 1 orang.

Hal ini sejalan dengan penelitian yang dilakukan oleh (Heriati, 2009) bahwa terdapat hubungan yang bermakna peran tenaga kesehatan dengan pemeriksaan kehamilan (K4). Jumlah tenaga yang terbatas dan ditambah peran ganda menyebabkan keterbatasan dalam memberikan layanan. Seperti ditulis (Marmi \& Margiyati, 2013) bahwa tiga faktor utama penentu perilaku atau sikap sehat adalah faktor predisposisi antara lain pengetahuan, sikap dan keyakinan, faktor pemungkin antara lain sarana prasarana dan fasilitas kesehatan dan faktor penguat yaitu faktor-faktor yang mendorong dan memperkuat perilaku

Hubungan kinerja tenaga kesehatan terhadap pelaksanaan ANC terpadu seperti dalam penelitian yang dilakukan oleh (Christiana , Sofoewan, \& Fitriani, 2016) bahwa terdapat faktor-faktor yang mempengaruhi kinerja tenaga kesehatan dalam pelayanan ANC terpadu diantaranya adalah umur, kepemimpinan, sikap dan motivasi yang baik.

Peran tenaga kesehatan dalam kelengkapan pemeriksaan kehamilan sejalan dengan penelitian yang dilakukan oleh (Fitrayeni, Suryati, \& Faranti, 2015) bahwa kunjungan ANC tidak lengkap banyak terdapat pada responden dengan peran bidan kurang baik dibandingkan peran bidan yang baik. Hasil analisis bivariat diketahui ada hubungan yang 
bermakna antara peran bidan dengan kelengkapan kunjungan ANC ( $p$ value $=0,003$ ).

Sarana prasarana juga mendukung ibu hamil untuk memperoleh pelayanan antenatal care dengan lengkap. Ketersediaan reagen untuk pemeriksaan laboratorium harus mencukupi sesuai dengan sasaran ibu hamil yang ada. Pemeriksaan laboratorium rutin dan khusus sangat bermanfaat untuk mendeteksi faktor risiko yang muncul pada ibu hamil. Hal ini sejalan dengan penelitian yang dilakukan Azizah dalam (Nuraisya, 2018) bahwa ANC terpadu penting dilaksanakan untuk mendeteksi adanya masalah dalam kehamilan. Hal ini menunjukkan betapa pentingnya pelaksanaan ANC terpadu yang dilaksanakan oleh Puskesmas yang memiliki sumber daya manusia dan sarana laboratorium yang lebih memadai.

Perlunya peningkatan kesadaran masyarakat untuk periksa hamil seawal mungkin lebih ditingkatkan melalui kerjasama lintas sektoral. Dukungan keluarga masyarakat dan lintas sektoral berpengaruh terhadap perubahan perilaku kesehatan seperti ditulis (Marmi \& Margiyati, 2013) bahwa ada lima determinan perilaku yaitu adanya niat, Dukungan dari masyarakat, terjangkaunya informasi adanya otonomi/kekebasan pribadi dan adanya kondisi dan situasi yang memungkinkan.

Kelengkapan ibu dalam memperoleh pelayanan ANC terpadu dipengaruhi kepatuhan ibu dalam melakukan pemeriksaan. Tingkat pendidikan, mempengaruhi kelengkapan ibu dalam memperoleh pelayanan ANC sejalan dengan penelitian (Rachmawati, Puspitasari, \& Cania, 2017) kepatuhan ibu hamil dalam melakukan kunjungan Antenatal Care (ANC) dipengaruhi oleh faktor usia, tingkat pendidikan, sikap, jarak tempat tinggal, penghasilan keluarga, sarana media informasi, dukungan suami, dukungan keluarga serta dukungan dari petugas kesehatan.

Peningkatan kesadaran masyarakat dalam pemeriksaan kehamilan dapat dilakukan melalui iklan layanan masyarakat. Iklan layanan masyarakatdapat melalui audio visual yang menarik ditambah leaflet, poster, pulpen, kalender kehamilan, totebag dan mug. Dengan media tersebut ibu hamil dapat melihat lebih nyata dampak yang ditimbulkan apabila ibu hamil tidak melakukan pemeriksaan dengan lengkap (Setiono, Mulyanto, \& Haryadi, 2015).

\section{KESIMPULAN DAN SARAN}

Pelayanan Antenatal Care Terpadu yang lengkap sesuai standar $10 \mathrm{~T}$ sebanyak 144 orang (72\%) dan ibu hamil yang memperoleh pelayanan ANC kurang lengkap 57 orang (28\%). Ibu hamil diharapkan segera mungkin melakukan pemeriksaan kehamilan setelah diketahui hamil, sehingga memperoleh pemeriksaan kehamilan sesuai standar karena dapat mendeteksi adanya faktor-faktor risiko yang muncul seawal mungkin, diharapkan komplikasi bisa diminimalkan dan diberikan penanganan sesegera mungkin.

\section{REFERENSI}

Addina, N. (2018). Hubungan Usia dan Tingkat Pendidikan Ibu hamil terhadap Kepatuhan Melaksanakan Ante Natal Care (ANC) di RSI Pekajangan. Publikasi Ilmiah.

Benson, R. c., \& Pernoll, M. I. (2008). Buku Saku Obstetri dan Ginekologi. Jakarta: EGC.

Christiana , E., Sofoewan, S., \& Fitriani, H. (2016). Faktor-faktor yang berhubungan dengan kinerja Tenaga Kesehatan Dalam Pelayanan Antenatal Care Terpadu. Jurnal Kebidanan dan Keperawatan, 135-142.

Corneles, S. M., \& Losu, F. N. (2015). Hubungan Tingkat Pendidikan Dengan Pengetahuan lbu Hamil Tentang Kehamilan Risiko Tinggi. Jurnal IImiah Bidan.

Creswell, J. W. (2017). Research Design Pendekatan Kualitatif,kuantitatif dan Mixed. Yogyakarta: Pustaka Pelajar.

Dinkes DIY. (2017). Profil Kesehatan. Yogyakarta: Dinkes DIY.

Fitrayeni, Suryati, \& Faranti, R. M. (2015). Penyebab Rendahnya Kelengkapan Kunjungan Antenatal Care Ibu Hamil di Wilayah Kerja Puskesmas Pegambiran. 
Jurnal Kesehatan Masyarakat Andalas, 101-107.

Heriati. (2009). Faktor-faktor yang mempengaruhi rendahnya Cakupan kunjungan ulang Pemeriksaan Kehamilan (K4) di Puskesmas Sei Nyamuk tahun 2008. Skripsi FKM UNAIR.

Hipson, M. (2016). Hubungan antara Umur, Paritas dan Pendidikan dengan Kejadian Eklapmsia di Rumah Sakit Muhammadiyah Palembang. Temu IImiah Hasil Penelitian dan Pengabdian Masyarakat RAKERNAS AIPKEMA.

Irianti, S. (2017). Determinan Kunjungan K4 pada ibu hamil Trimester III di Poli Kebidanan RSUD Berkah Kabupaten Pandeglang. Faletehan health Jurnal.

Kemenkes. (2014). Pedoman Antenatal Care Terpadu.

Kompas. (2016). Terlalu Lelah Bekerja Pengaruhi Ukuran Janin.

Kusmiyati, Y. (2010). Perawatan Ibu Hamil. Yogyakarta: Fitramaya.

Kusyanti, F., \& Maydianasari, L. (2019). Studi Kasus Kinerja Bidan Dalam Pelaksanaan Antenatal Care (ANC) Terpadu Di Puskesmas Wilayah Kerja Dinas Kesehatan Kabupaten Magelang Jawa Tengah. Jurnal Medika Respati, Vol 14 Nomor 1.

Lesilolo, T. N., Engka, J. N., \& Wunguow, H. I. (2016). Hubungan Pemberian Tablet Besi Dan Antenatal Care Terhadap Kadar Hemoglobin Pada Ibu Hamil di Kabupaten Bolaang Mongondouw Utara. Jurnal e-Biomedik (eBm), Volume 4 Nomor 1.

Makmun, I., \& Ismarwati. (2016). Pengaruh Pemberian Pendidikan Kesehatan Terhadap Sikap Mengkonsumsi Tablet Fe Pada Ibu Hamil. Jurnal Kebidanan dan Keperawatan, 95-102.

Marmi, \& Margiyati. (2013). Pengantar Psikologi Kebidanan. Yogyakarta: Pustaka Pelajar.
Mufdlilah. (2009). Panduan Asuhan Kebidanan Ibu Hamil. Yogyakarta: Nuha Medika.

Nuraisya, W. (2018). Deteksi Risiko Tinggi Kehamilan pada Pelayanan ANCTerpadu di Puskesmas Bendo Kabupaten Kediri. Jurnal Kesehatan Andalas, 7(2).

Oktavia, N., \& Lolli, E. Z. (2018). Pelaksanaan Konseling pra-tes meningkatkan tingkat Pemahaman Ibu hamil tentang pemeriksaan HIV dan Hepatitis B . Jurnal Keperawatan dan Kebidanan Aisyiyah, 40-48.

Onyeajam, D. J., Xirasagar, S., Khan, M. M., Hardin, J. W., \& Odutolu, O. (2018). Antenatal Satisfaction in a developing country: a cross-sectional strudy from nigeria. BMC Public health, 18:363.

Puskesmas Tepus II. (2018). Laporan PWS KIA.

Puspitasari, E., Hakimi, M., \& Nurhidayati, E. (2017). Hubungan Faktor Sosiodemografi dengan Kunjungan Antenatal Care. Jurnal Kebidanan dan Keperawatan, 55-61.

Rachmawati, A. I., Puspitasari, R. D., \& Cania, E. (2017). Faktor-faktor yang mempengaruhi Kunjungan Antenatal Care (ANC). Majority, Volume 7 No 1.

Saminem. (2009). Kehamilan Normal. Jakarta: EGC.

Septiningsih. (2018). Hubungan Pelaksanaan Standar Pelayanan Antenatal Care (ANC) dengan Deteksi Risiko Tinggi Pada Ibu hamil Oleh Tenaga Kesehatan di Puskesmas Gamping I Sleman.Skripsi. Yogyakarta: Universitas 'Aisyiyah Yogyakarta.

Setiono, T., Mulyanto, E., \& Haryadi, T. (2015). Meningkatkan Kesadatran Ibu hamil Terhadap antenatal Care (Pemeriksaan Kehamilan) melalui Iklan layanan Masyarakat.Skripsi. Kudus: Universitas Dian Nuswantoro 